\title{
Understanding "Geopolitics" in an Era of Globalization
}

John Agnew,

UCLA, Department of Geography jagnew@geog.ucla.edu

Artigo recebido em 17/10/2015 e aceito para publicação em 14/11/2015

DOI: $10.12957 /$ tamoios.2015.19221

\section{SUMMARY}

An older European-Enlightenment geopolitical imagination was lost in the late nineteenth century with the rise of naturalized understandings of inter-state and imperial relations that saw states and empires in terms of biological competition conditioned by relative location on the earth's surface. The word "geopolitics" emerged in that context and since that time the term has had to contend with this original sin. Arguably, however, Montesquieu and Voltaire in their references to Alexander the Great had a somewhat different conception of geopolitics in mind: one in which reciprocity and exchange between places as well as the redistribution of resources from colonies to homeland are at work. It is this broader sense of the word that has been revived over the past fifty years in the course of attempts at linking the global political structure of states, empires, and other political authorities to what can be called the "globalization era." The broader understanding of geopolitics is by no means restricted to this era, as the reference to the Enlightenment period should make clear. But it has become an increasingly attractive alternative. I discuss four aspects of the connection between geopolitics construed in the broader meaning and the globalization that the world economy has experienced over the past fifty years. The first is to challenge the idea that geopolitics in the broad sense is "opposed" to globalization. I then turn to what I see are the three dimensions of geopolitics in an era of globalization: the geopolitics of globalization, the geopolitics of development, and the geopolitics of global regulation. From this perspective, Montesquieu and Voltaire offer a much better inspiration for understanding world politics than do the geopolitical writers of the early twentieth century such as Kjellen and Mackinder. 
The famous European-Enlightenment philosophers Montesquieu and Voltaire saw the ancient Macedonian Emperor Alexander the Great in his day as having created a "great revolution" by having changed the "face of commerce" across the world as then known. Writing in the eighteenth century, they understood "commerce" very widely: it referred not only to economic and intellectual exchange between places but also to the reciprocal relations and exchanges among peoples, states and sexes. Perhaps Alexander's greatest virtue was that even as he conquered he was held to have respected the customs of those he conquered and encouraged commerce rather than the territorial stasis Enlightenment historiography associated with the Persian Empire. Alexander provided a model for eighteenth-century European empire-builders to emulate (Briant 2012). This imagination was lost in the late nineteenth century with the rise of naturalized understandings of interstate and imperial relations that saw states and empires in terms of biological competition conditioned by relative location on the earth's surface. The word "geopolitics" emerged in that context and since that time the term has had to contend with this original sin. Arguably, however, Montesquieu and Voltaire in their references to Alexander the Great had a somewhat different conception of geopolitics in mind: one in which reciprocity and exchange between places as well as the redistribution of resources from colonies to homeland are at work. It is this broader sense of the word that has been revived over the past fifty years in the course of attempts at linking the global political structure of states, empires, and other political authorities to what can be called the "globalization era" (Agnew 2003).

In this chapter I discuss four aspects of the connection between geopolitics construed in this broader meaning and the globalization that the world economy has experienced over the past fifty years. The first is to challenge the idea that geopolitics is "opposed" to globalization. This contention reflects adherence to the territorial "necessity" of state-imperial expansion characteristic of classical nineteenth century understanding of geopolitics (Agnew and Corbridge 1995). I then turn to what I see are the three dimensions of geopolitics in an era of globalization: the geopolitics of globalization, the geopolitics of development, and the geopolitics of global regulation. These, respectively, involve discussing the role of the United States in enabling and stimulating much of what goes for economic globalization (increased trade and investment around the world and so on), identifying the capacities of different states in light of different colonial histories and histories of statehood to engage in successful 
$\overline{\text { strategies of economic growth and thus capture the presumed benefits of globalization, }}$ and showing the new agencies of global regulation, both public and private, that are addressing and enabling current patterns of globalization often independently of any single state or grouping of states. From this perspective, Montesquieu and Voltaire offer a much better inspiration for understanding the world today than do the geopolitical writers of the early twentieth century such as Kjellen and Mackinder.

\section{GEOPOLITICS VERSUS GLOBALIZATION}

It is common to see geopolitics and globalization as opposites with respect to how the world works. If the former is associated primarily with geographical determinism in channeling the universal urge for territorial expansion on the part of all states, the latter is seen as creating an interdependent and "flat" world in which flows of goods, people and capital displace the territorialized world of inter-imperial rivalries that characterized the past. Brian Blouet (2001) has devoted an entire book to justifying this opposition. He writes: "Geopolitical policies seek to establish national or imperial control over space and the resources, routeways, industrial capacity and population the territory contains,' whereas "globalization is the opening of national space to the free flow of goods, capital, and ideas. Globalization removes obstructions to movement and creates conditions in which international trade in goods and services can expand" (Blouet 2001, 1). Yet, historically such a clear-cut distinction makes little sense. Certainly, the period from 1875 until 1945 can be reasonably characterized as one in which inter-imperial rivalry tended to win out over open trade and so and the Cold War from 1945 until 1991 involved a major geopolitical fracture between a relatively freeflowing West and a relatively autarchic East. Classic geopolitics developed in the first period and represented an effort at justifying imperialism in naturalistic terms of space and race (Ashworth 2013). But right across the periods in question there were systematic efforts on the part of some governments, particularly in Britain and the United States, and businesses looking to expand beyond home shores, to reduce and remove barriers to trade and investment. These increasingly came to fruition during the Cold War and since the 1990s have expanded to include much of the world. Globalization, then, was incipient within the territorialized conflicts of the twentieth 
century. It was not opposite but in fact a strategic option pursued by some actors within the confines of the geopolitical conflicts that wracked the century.

The opposition relies on posing two spatial ontologies as necessarily antithetical: a world of territorial and self-aggrandizing states and a world of networked flows independent of states. These are seen as competing paradigms of modernity. In this construction territorialization is opposed to open circulation. In fact, they have always co-existed with one another if historically either one or the other has had periods of relative ascendancy. More specifically, the territorial state has had a historical geography to its formation and diffusion that suggests anything other than a straightforward historic victory of territorial containment over open circulation. Global and territorial spaces have long coexisted. The modern state system did not appear overnight and fully formed as a result of the settlement of the European religious wars enshrined in the Treaty of Westphalia in 1648 and globalization did not spring up instantaneously and spontaneously in the 1970s or 1980s. If globalization discourse tends to suffer from hyperbole: "portraying the transformation from the modern Westphalian to the globalized postmodern world system in terms of a caesural rupture of extremely short duration" (Larkins 2010, 199), geopolitics is seen as anachronistic because of its association with early twentieth-century imperial rivalries. The purpose of this chapter is show what each of them actually owes to the other.

There is a passing affinity between this approach and that of Carl Schmitt's writing on The Nomos of the Earth (2003 [1950]). It is worth mentioning here to distance the approach from what might seem to be an apparent alternative. In The Nomos, Schmitt, a German conservative legal scholar and erstwhile supporter of the Nazi regime, conceived of geopolitics in terms of competing spheres of influence in which a regional hegemon would dominate within a given area beyond its own territorial borders (Elden 2011). Modeled on the way the US Monroe Doctrine had evolved to limit interventions in the Western hemisphere to the United States, Schmitt attempted an integration of the geopolitical and the economic by positing that dominant powers should not seek to annex territory but to integrate surrounding areas within their spatiale Bereich or spatial sphere of influence. Arguably, this is more or less what happened to large parts of the world during the Cold War. The emergence of the European Union as a supra-regional authority has reinforced the attractiveness of the logic. This gives Schmitt's work an apparently prophetic quality. Yet, there are three 
major problems with this approach beyond the problematic reputation of its author. One is that it is resolutely ignorant of the role of actors in world politics other than states in general and the presumably dominant regional powers (such as the United States, Russia or Germany) in particular. A second is that the proposed Grossräumen or regional spheres identified as such may exist but the role of singular dominating powers is far from obvious in most possible ones and geopolitical considerations may not always be more important than economic or cultural ones (as in South Asia or the Middle East, for example). Finally, globalization as a set of processes potentially operating worldwide through technological changes in communications and transportation technologies and stimulated by government policies encouraging trade and investment across state borders nowhere figures in Schmitt's theoretical calculus. Even while eschewing annexation as the motivation for Raumhoheit or spatial supremacy, Schmitt cannot escape from the territorialized logic of economic autarchy that he inherited from his longstanding commitment to the political theology of the Volk or people (German or otherwise). His anti-liberalism trumps his ability to think of a world in which a state-centered geopolitics not only co-exists with but guides planetary political-economic order. It is the sense of a fading or lost world that informs the overall perspective of Schmitt and other apostles of absolute territorial sovereignty on the part of dominant powers: "Territorial sovereignty was transformed into an empty space for socio-economic processes. The external territorial form with its linear boundaries was [legally] guaranteed, but not its substance, i.e. not the social and economic content of territorial integrity" (Schmitt 2003 [1950], 252 quoted in Coleman 2011, 137).

It is useful perhaps to make the case for the geopolitics of globalization in empirical terms. Using different terminology, a range of features of contemporary world politics can be ascribed to geopolitics. These include the incidence of interstate conflicts, the occurrence of civil wars, and the unevenness of economic development around the world. These always have putative geopolitical as well as economic causes. In other words, that acts of governments and other public and private authorities have profound effects on both country-by-country and local differences in conflict potential and economic development. Globalization is also thus far from being a spontaneous, purely economic process. It is also the progeny of geopolitical action. Three ways in which geopolitics underpins globalization can be identified as constituting geopolitics in the era of globalization. The first, at the global level, is the geopolitics of globalization or 
the way in which the world's most powerful state for the past seventy years, the United States, has facilitated the opening up of the world economy. This has obviously not been without resistance as can be seen, for example, in the Arab World, with efforts by militant Islamist groups to turn away from any paradigm of modernity as irredeemably tainted by its foreign and/or Western origins and in Russian government efforts to reestablish Russia as a regional hegemon even if this imposes massive costs on its own territorial economy. The contemporary world is not one without contradictions. The second, at the national level, is the geopolitics of development with reference to the differences between states with respect to their mobilization of populations to pursue economic development and the investment in public goods and infrastructures to enable this pursuit. In the face of globalization, some countries, China and South Korea would be examples, have managed to reorganize their economies to benefit from the changes. Other governments have been much less able and willing to do so. The final is the increasingly complex system under globalization of what can be called "low geopolitics" or the economic-regulatory activities carried out by relatively independent private and public agencies and the emergence of intermediary jurisdictions particularly tax havens and global financial centers in world cities through which the invoices of world trade and investment increasingly circulate. This is geopolitics without the drama of military strategies involving carrier task forces and so on but with real impacts on everyday lives around the world.

\section{GEOPOLITICS OF GLOBALIZATION}

Globalization as we understand it today began in the nineteenth century, even if it had earlier roots in European colonial expansion (Wallerstein et al. 2013). The technological and managerial changes following the industrial revolution led to massive increases in demand for resources, outlets for markets and returns on investments all facilitated by foreign expansion. If in Europe a balance-of-power regime encouraged interstate competition outside of the region, the arrival of new state actors such as Germany, Italy, Japan and the United States onto the global scene disrupted the Britishdominated globalization of trade and finance worldwide. British governments provided the international legal and financial rules including the monetary gold standard that greased the wheels of nineteenth century global commerce. This ended badly when up- 
and-coming powers such as Germany with more territorialized conceptions of politicaleconomic organization and feeling closed out of existing imperial arrangements challenged the political-military status quo. Much of the twentieth century was spent fighting and recovering from the wars that this geopolitical system of inter-imperial rivalry entailed (Agnew and Corbridge 1995).

In the aftermath of World War II, the United States took on the global role of sponsoring a return to the sort of open world economy relinquished by a now-declining Britain. The impetus to this came both from the desire of US industry to benefit from worldwide expansion and the perceived threat to this from the Soviet Union and its autarchic model of economic development. The roots of contemporary globalization can be said to lie, at least in part, in the containment of the Soviet Union: the putative strategy at the center of US Cold War policy. The internal decay of the Soviet model meant that by the 1980s the United States had become the world's most important country economically and militarily. Its military capacity, at least if measured by share of national economy devoted to military spending, is without peer: equal to the next twelve largest spenders put together. Whether this always guarantees equivalent success in specific conflicts, from the Vietnam War to recent fiascos such as the 2003 invasion and occupation of Iraq and the inability to coerce Russia in Ukraine in 2014, is open to much doubt. Nevertheless, US economic and cultural influence around the world has generally proved very successful, even though openly challenged during the Cold War until 1991 by the competing political-economic model of the Soviet Union based on central government economic planning as opposed to the private ownership of land and industry championed by the United States. US governments were compelled by their ideological struggle with the Soviet Union to favor lifting restrictions on trade and commerce, though historically protectionist of their own domestic market. The US replaced Britain in using its financial and military power both acquired as outcomes of World War II when the other world powers very largely exhausted to support the development of the global legal and financial norms necessary for the overall expansion of commerce. Pushing for this were American businesses that saw opportunities for both investment and consumer markets around the world. Four examples of institutional/technological changes serve to show how much the organizational and technological infrastructure of post-1970s globalization has relied on US geopolitical status and capacity. 
First of all, removing barriers to trade such as tariffs and quotas became an important goal of US foreign policy in the 1950s and 1960s. US governments sponsored all of the major rounds of the General Agreement on Tariffs and Trade (GATT) to open up world trade in manufactured goods. On agriculture and services it remained much more circumspect, showing how much it was US industrial corporations and banks that favored an opening of the world economy more than other business interests. Figure 1 shows the net reduction in GATT member average tariffs between 1947 and 1991 and the parallel course of overall trade and economic growth. Trade amounted for an increasing share of overall global economic growth over this period. Thus was laid the groundwork for the explosion of world trade, the expansion of manufacturing supplychains for parts and components across international borders and the dramatic opening up previously closed economies such as that of China.

Figure 1: The global reduction of tariffs due to rounds of GATT negotiations (1947-91) and world trade and GDP increases (1950-91).

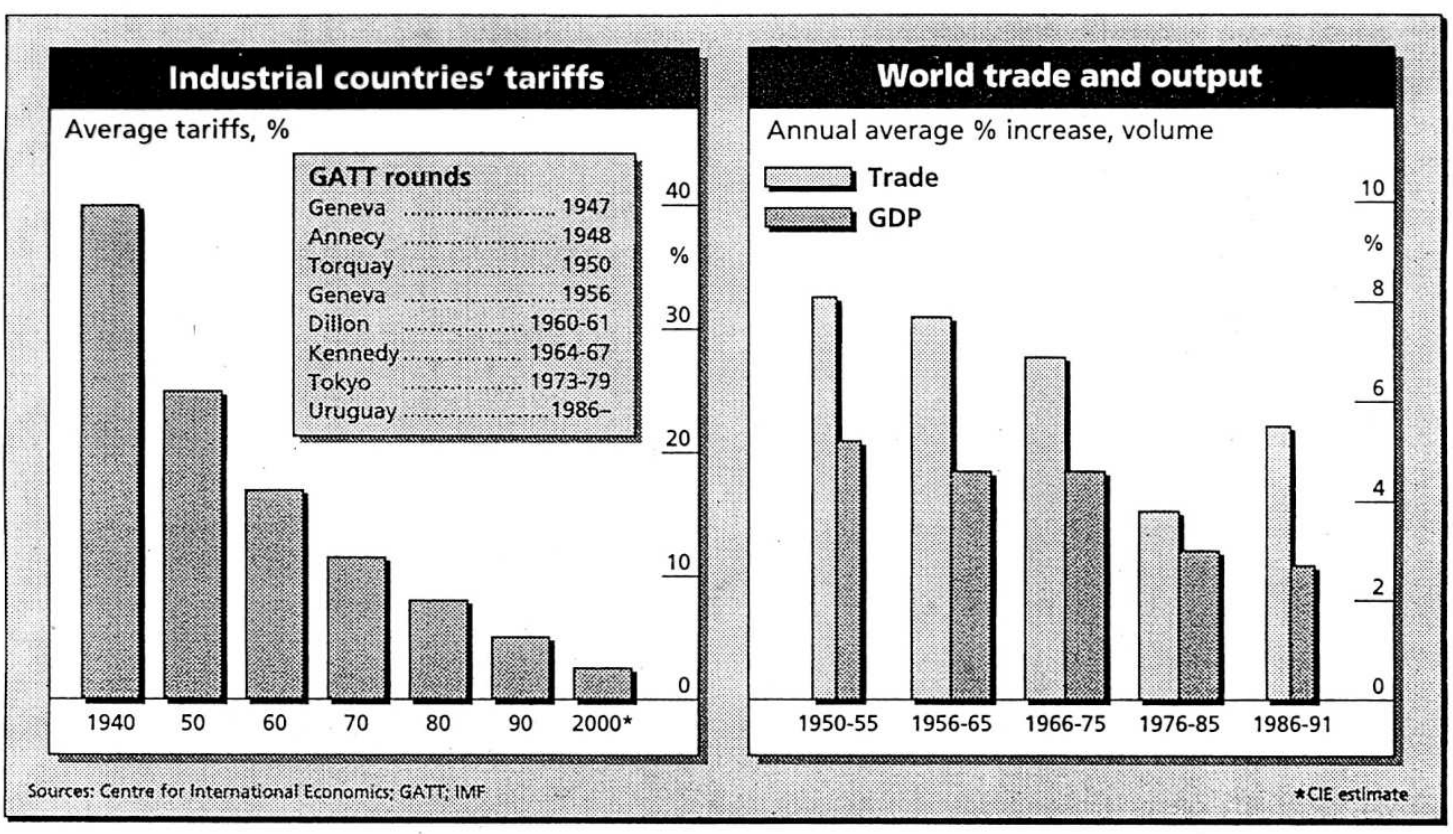

Second, as the world's largest economy in 1945 and thereafter, the US also came to provide the world's main currency for world trade. This made the US central bank, the Federal Reserve, the world's most important monetary institution. The value of other currencies in world commerce was fixed to the value of the US dollar with central banks managing the process of rate setting within narrow bands of fluctuation. The decision by the US government in 1971 to shift from the governmentally managed monetary system established in 1944 by the US and other countries (as a result of the 
Bretton Woods Agreement) to a free-floating exchange rate in which the value of the US dollar would fluctuate relative to other currencies as a result of competitive bidding in open markets was crucial in creating the global financial system we have today. It was not a deliberate decision to change the global monetary system so much as a tactical maneuver by the Administration of President Nixon to reduce the US balanceof-payments deficit and encourage US exports by devaluing the currency (Pearlstein 2008, 601-3; Gowa 1983). Since then the world monetary system has been based increasingly around floating exchange rates as the relative values of more and more currencies are set in foreign-exchange markets rather than by governments or national central banks. This set the scene not only for a globalized financial system (when floating exchange rates were joined by removals of controls on capital movements) but also for the global transmission of financial risks as with the 2008 global financial crisis brought on by worldwide bank purchases of US sub-prime mortgage securities. With the rise of other economies under globalization, such as China, Brazil, and so on, the question arises of how long the US dollar can continue to dominate as the medium of world trade (Eichengreen2011).

Third, large US-based multinational businesses and banks were important sponsors and beneficiaries of this opening up of the world economy under US government auspices that has in turn enabled the global supply chains and massive changes in global patterns of economic development since the 1970s. But the actual technologies used in this process, labeled generally by the term "logistics," such as the use of shipping containers and the organization of supply chains bring together components from multiple sites for assembly and sale elsewhere, have relied on models drawn very much from the US military and its preparations for projecting and managing forces on many fronts at once. Indeed, the nuts and bolts of globalization as a means of organizing the production and circulation of goods, capital and people rely fundamentally on logistics. By way of example, containerization was first used on a large scale by the US military. Only later did its radical reduction in time taken to load and unload ships lead to its widespread civilian adoption. Containerization is an absolute prerequisite for the just-in-time (JIT) system at providing components through the global supply chains that now connect computer manufacturing across the US, Taiwan and China. Thus, as Deborah Cowen $(2014,41)$ argues: "For JIT to become a globalized system, inputs and commodities had to be coordinated and transported 
quickly across space. U.S. military procurement laid many of the infrastructural foundations for this work during the Korean War. With the military's use of containers to manage massive supply chains during the Vietnam War, container shipping became firmly entrenched."

Fourth, and finally, the very possibilities of cross-border corporate and financial ties have been realized because of the spread of legal norms and procedures that are managed by global law firms, based primarily in New York and London, that mediate in stock offerings, inter-firm disputes, and mergers and acquisitions activities (Sokol 2007). One reason London has retained its central role in the world economy is the inertia associated with its development of a court system and legal norms governing corporate law that date back to the nineteenth century. But New York is increasingly important as the source of the law that is central to globalization. US legal norms and practices now dominate globally in relation to many transnational transactions (e.g. Trubek et al. 1994; Buxbaum 2006). US procedural practices such as class action and pretrial discovery have spread worldwide. This is not so much by the explicit adoption by states of such procedures but more in terms of the private practice of law involving primarily non-state actors. The geopolitical status of the United States obviously informs this diffusion process. Legal systems have always been syncretic or absorptive of foreign practices to one degree or another even when primarily, for example, civil (statutory) or common (judges make law) law traditions. What is novel is the extent to which today the wheels of globalization are oiled by the transnational movement of US legal practices (Brake and Katzenstein 2013). Such as it is this transfer of US practice into transnational law fosters rather than limits corporate power (Barkan 2013).

These trends all suggest, however, that once under way and with sufficient support worldwide, globalization does not necessarily need continuing "geopolitical support." The frequently voiced view in the United States is different. As Thomas Friedman $(2000,467-8)$ puts it "the globalization system cannot hold together without an an activist and generous American foreign policy." Yet, it is undoubtedly the case that globalization requires underlying institutional direction and practical support. Whether international institutions and regulatory agencies can do this remains moot. If US and other governments turn away from globalization the lesson from the early twentieth century suggests that globalization itself could falter. 


\section{GEOPOLITICS OF DEVELOPMENT}

Globalization works through as well around governmental institutions. It is a myth that globalization leads to the "end" of the state (Mann 1997). In fact, much of the impetus behind globalization lies in taking advantage of differences in factor endowments and fiscal and monetary policies in different countries. In this context, some governments have been more adept than others at exploiting the opportunities provided by a more open world economy. The map of the most globalized countries according to one set of empirical indicators reveals that the world is far from "flat" or uniform in terms of active involvement in the world economy. Small European economies tend to be the most open followed by other European countries, the United States and Canada, New Zealand, Singapore, Hong Kong, and Malaysia. In terms of trade, holdings of foreign assets (particularly US Treasury bonds), and "weight" within the world economy, South Korea, Japan, and China are also very important. Given its rapid rise from negligible significance as a player in the world economy before 1987 to its growth as the world's second largest economy by 2012, China's story is particularly interesting as an example of the geopolitics of development. China's great success in improving its level of economic development and reducing its number of poor people is not simply just a question of exploiting its vast pool of relatively cheap labor. Mobilizing populations and organizing insertion into global markets have been particularly important. The first, dependent in part on a degree of cultural homogeneity and acceptance of government popular legitimacy, makes it possible for foreign and domestic investors to expect maximum political stability and minimal workplace disruptions. The second requires a clear sense that some economic activities, banking, for example, need considerable government control, even as the country is opened up globally to exploit its comparative advantages in land, labor, or capital. Perhaps even more crucial is investment in infrastructures such as ports, railways, and highways and public goods such as general education and healthcare to produce propitious settings for profitable private investment. There is a clear connection between successful efforts at popular mobilization and infrastructure investment, on the one hand, and dramatic improvements in economic development, on the other.

But a number of different strategies can make sense depending on size of economy (population, infrastructure demands, etc.), resource base, governmental 
structure, and governmental efficacy. Large home economies allow for both economies of scale in production/consumption and import substitution. Historically, Brazil, India, and Mexico followed this approach. Russia, after having flirted with the world economy after the collapse of the Soviet Union, may be heading back in this direction. Regional supra-national authorities such as the European Union and NAFTA can provide such benefits while also maintaining state-level autonomy of various sorts. Countries with large resource bases, particularly ones with relatively inelastic demand but subject to depletion (such as oil), can bank on using sovereign-wealth funds to invest in assets both nationally and globally (Xu and Bahgat 2011). Many of the world's major oilproducing countries, from Kuwait and Venezuela to Norway, have such funds. But countries such as Singapore, Malaysia, China, and South Korea have also followed this strategy to a degree. Smaller states can turn themselves into tax havens. Some US states (such as Delaware and Wyoming), Caribbean island neo-colonies (such as the Cayman Islands), Luxembourg, Switzerland, Ireland, the Netherlands, and Britain (since the 1980s) have taken on at least some of the attributes of tax havens: allowing foreign companies and wealthy persons the advantages of domiciliary status to lower or eliminate income taxes, facilitating tax inversions (after mergers or acquisitions moving to the lowest tax jurisdiction available), and through transfer-price invoicing lowering taxes by means of booking revenues to the lowest tax jurisdiction in which a corporate subsidiary is located (frequently solely for this purpose) (Shaxson 2011). Obviously, these development strategies tend to be at the expense of other jurisdictions. But the lobbying power of the businesses and individuals that benefit from them is such in those other jurisdictions that little or nothing can be done to eliminate the tax avoidance strategies upon which they are based.

At the other end of the continuum of development are many quasi- or even "failed" states that are unable to manage the possibilities on offer from globalization (Acemoglu and Robinson 2012; Jackson 1993). Some of this incapacity can be put down to the colonial histories of many state, particularly the lack of mapping between nation on the one hand and state on the other. While corruption is hardly a monopoly of such regimes, it is endemic in many post-colonial states, at least in part because of seeing government office almost entirely as a source of patronage. Colonies that later became independent states were often carved out by colonial powers (such as Britain, France, Spain, and so on) with little or no attention to their ethnic or national 
homogeneity. This makes establishing political legitimacy for national institutions especially difficult. At the same time, political institutions imposed from the outside rather than developed indigenously do not always travel well, so to speak. This is particularly the case when the economic recipes imposed by outside lending agencies discourage public investment and impose austerity budgets. In the aftermath of the Cold War the ending of those pressures from the United States and the Soviet Union that kept certain states together through massive infusions of aid as a result of complementary competition have opened states up to a "hollowing out" as different sects, tribes, clans, and regional groups vie to establish their own political dominance or secession. This latter trend, of course, is not restricted to weak states but also afflicts such longestablished strong states as Britain and Spain where the European Union provides a broad overarching governance framework within which quite small states can flourish.

Whatever the precise strategy of development chosen, it is clear that economic growth in the era of globalization depends crucially on the capacity to find a niche within the wider global economy. While this is particularly true for smaller states, larger ones can also benefit enormously from collective mobilization on behalf of clear goals. The structural impediments imposed by global geopolitical realities, however, make some options more available than others. For a large subset of the world's states, particularly those with the most negative and long lasting colonial experiences, largely located in Africa and the Middle East, the fruits of globalization, if they are such, remain a distant goal.

\section{GEOPOLITICS OF REGULATION}

With the onset of globalization since the 1970s, world economic development is increasingly regulated not just by governments within countries but also by increasingly influential private, quasi-public and international organizations. Arguably the growth in private and quasi-public agencies is the product of the erosion of the public-private divide with the revolving door in personnel between government and private business, popular and business hostility (particularly in the United States) to government regulation (at least before the financial collapse of 2008), the absence of much intergovernmental regulation, and the explosion of transnational transactions to which established states are ill-equipped to respond (Cooley and Spruyt 2009). As Janine Wedel $(2004,217)$ describes this trend: "Spurred by two decades of deregulation, 
$\overline{\text { public-private partnerships and a worldwide movement towards privatization, non-state }}$ actors now fulfill functions once reserved for government. Moreover, the inclination to blur the 'state' and 'private' spheres now enjoys global acceptance. An international vernacular of 'privatization,' 'civil society,' 'non-governmental organizations' and other catch terms de-emphasizing the state is parroted from Washington to Warsaw to Wellington." The decisions of the myriad of new transnational organizations can have major effects on the course of globalization. They constitute the actors in what can be called "low geopolitics" to distinguish it from the "high geopolitics" of interstate hierarchy and inter-imperial rivalries. Even though this trend has powerful sponsors in the United States, the European Union and among the businesses that lobby in the traditional corridors of geopolitical power, it gives rise to actors who are only accountable indirectly to any recognizably public political masters.

In the first case are international standard setting and regulatory agencies. These are arrayed across two dimensions: whether they are essentially private or public (in terms of responsibility) and whether they are market or non-market driven (in terms of decision mechanisms) (Büthe and Mattli 2011) (Table 1). International financial and development organizations such as, respectively, the International Monetary Fund and the World Bank are the best known of these. They are intergovernmental organizations but follow their own agendas set by their professional staffs with votes weighted towards their major funders, in particular the United States. They support governments in difficult economic circumstances in return for those governments following policy prescriptions designed by those organizations. An important example of the private/ market organizations would be the major credit-rating agencies, which rate the riskiness of bonds issued by businesses and governments. Their decisions are based on the claim that they have specialist knowledge and "independence" not available to governmental organizations. When governments try to raise revenues by selling bonds, therefore, they are subject to the authority exercised by private credit-rating agencies such as Moody's, Standard and Poor's and Fitch when doing so. The recent Eurozone crisis showed their importance relative to that of public agencies such as the IMF and the European Central Bank whose decisions reflected anxieties over decisions by the credit-rating agencies. In the public/market category are organizations that regulate mergers and acquisitions and the monopoly pricing and insider trading practices of giant businesses often well beyond home shores such as the US Federal Trade Commission and the Securities and 
Exchange Commission. Finally, there are a host of standard setting organizations that fir into the private/non-market category. These are the organizations that have come into their own in recent years as filling regulatory roles simply not addressed by public bodies of any stripe. They set accounting rules, product safety specifications, rules about derivatives and other financial products and so on. They may seem mundane in terms of what they do. But they are exactly the agencies that Büthe and Mattli (2011) dub the "new global rulers."

Table 1: Categories and examples of global standard setting and regulatory agencies

\begin{tabular}{|c|c|}
\hline Public/Non-Market & Private/Market \\
\hline ILO, IMF, Kyoto Protocol & Microsoft (Windows) \\
\hline World Bank & FSC, CSR setters \\
\hline \multicolumn{2}{|l|}{ CRAs } \\
\hline Public/Market & Private/Non-Market \\
\hline EU Competition vs US FTC & IASB, IEC, ISO, ISDA \\
\hline \multicolumn{2}{|l|}{ SEC } \\
\hline \multicolumn{2}{|c|}{ NB: ILO = International Labor Organization IASB = International Accounting Standards Board } \\
\hline $\mathrm{IMF}=$ International Monetary Fund & IEC $=$ International Electrotechnical Commission \\
\hline FSC $=$ Forest Stewardship Council & ISO = International Organization for Standardization \\
\hline \multicolumn{2}{|c|}{ CSR setters $=$ Corporate Social Responsibility } \\
\hline CRAs $=$ Credit-Rating Agencies & ISDA = International Swaps and Derivatives Association \\
\hline \multicolumn{2}{|l|}{ EU Competition Directorate } \\
\hline \multicolumn{2}{|l|}{ US FTC $=$ Federal Trade Commission } \\
\hline SEC $=$ Securities and Exchange Con & ssion \\
\hline
\end{tabular}

Source: based on Büthe and Mattli (2011)

In the second case, most national central banks today have a high degree of political independence from their governments. For example, the Bank of England, long subject to close supervision by the British Treasury, has been independent of such influence since 1997. The European Central bank, invented in 1999 to govern the new Euro currency, likewise exercises a power separate from that of the member states in the Eurozone (the 17 members of the European Union that since 1999 have come to share the same currency). This means that they make decisions about how much currency to issue, interest rates, and exchange rate supports with an eye on global markets rather than just their own governments. At the same time, much of the world's private financial economy is increasingly moving "offshore" to avoid as much national and 
global regulation as possible (see Table 1). To take advantage of low or nonexistent corporate and personal income taxes, many transnational businesses now incorporate in tax havens such as the Cayman Islands. Major global financial institutions in New York and London provide the nerve centers for this cross-jurisdictional circulation of corporate profits. Central banks increasingly try to coordinate their activities to manage these offshore flows. In the Bank for International Settlements they even have their own joint bank to coordinate their efforts at regulating global finance (Lebor 2013). The contradiction between the desire of large countries with dependent populations and development plans to retain tax revenues and the increasing desire and opportunity of wealthy individuals and businesses to avoid or evade taxes plagues the contemporary system of international financial regulation. A major crisis is brewing in that the massive avoidance of taxes not only creates opportunities for "money laundering" of illegal activities, it also reduces the revenues that governments need in providing the public investments necessary for successful economic development.

\section{CONCLUSION}

Geopolitics and globalization have always gone together rather than been antithetical. The claim that they have been opposites over the course of the past century or so does not bear close examination. In this paper I have tried to show how they have been mutually entailed by focusing on three moments of their relationship with globalization: with respect to the origins of contemporary globalization in the policies pursued by successive US governments after 1945; the close connection between geopolitical history and status and the capacity to exploit the possibilities of globalization; and the emergence of new regulatory and standard-setting agencies under the sponsorship of major geopolitical powers but growing in authority in recognition of dominant states' limited ability to manage the explosion of transnational transactions on their own. Whether this virtual circle of geopolitics and globalization will continue into the future or in precisely the form it has taken so far is in the lap of the gods. What does seem clear is that thinking of geopolitics in the limited territorialized-competitive terms characteristic of its early twentieth century iteration offers little or no grasp of what has happened since. It is time to move on from the narrow inter-imperial cast of early 
twentieth-century geopolitics - Mackinder and company -- and the foolish policy advice it often leads its proponents to proffer.

\section{REFERENCES}

Acemoglu, D. and Robinson, J. (2012) Why Nations Fail: The Origins of Power, Prosperity and Poverty. New York: Crown.

Agnew, J. (2003) Geopolitics: Re-Visioning World Politics. Second Edition. London Routledge.

Agnew, J. and Corbridge, S. (1995) Mastering Space: Hegemony, Territory, and International Political Economy. London: Routledge.

Ashworth, L. M. (2013) Mapping a new world: geography and the interwar study of international relations. International Studies Quarterly 57: 138-49.

Barkan, J. (2013) Corporate Sovereignty: Law and Government under Capitalism. Minneapolis: University of Minnesota Press.

Blouet, B. (2001) Globalization and Geopolitics. London: Reaktion Books.

Brake, B. and Katzenstein, P. J. (2013) Lost in translation? Nonstate actors and the transnational movement of procedural law. International Organization 67: 725-57.

Briant, P. (2012) Alexandre des Lumières: fragments d'histoire européene. Paris: Gallimard.

Büthe, T. and Mattli, W. (2011) The New Global Rulers: The Privatization of Regulation in the World Economy. Princeton NJ: Princeton University Press.

Buxbaum, H. (2006) Transnational regulatory litigation. Virginia Journal of International Law 46: 251-317.

Coleman, M. (2011) Colonial war: Carl Schmitt's deterriorialization of enmity, in S. Legg (ed.) Spatiality, Sovereignty and Carl Schmitt: Geographies of the Nomos. London: Routledge, pp. 127-42.

Cooley, A. and Spruyt, H. (2009) Contracting States: Sovereign Transfers in International Relations. Princeton NJ: Princeton University Press.

Cowen, D. (2014) The Deadly Life of Logistics: Mapping Violence in Global Trade. Minneapolis: University of Minnesota Press.

Eichengreen, B. (2011) Exorbitant Privilege: The Rise and Fall of the Dollar and the Future of the International Monetary System. New York: Oxford University Press. 
Elden, S. (2011) Reading Schmitt geopolitically: nomos, territory and Grossraum, in S.

Legg (ed.) Spatiality, Sovereignty and Carl Schmitt: Geographies of the Nomos. London: Routledge, pp. 91-105.

Friedman, T. (2000) The Lexus and the Olive Tree. New York: Anchor.

Gowa, J. (1983) Closing the Gold Window: Domestic Politics and the End of Bretton Woods. Ithaca NY: Cornell University Press.

Jackson, R. H. (1993) Quasi-States: Sovereignty, International Relations and the Third World. Cambridge: Cambridge University Press.

Larkins, J. (2010) From Hierarchy to Anarchy: Territory and Politics before Westphalia. New York: Palgrave Macmillan.

Lebor, A. (2013) Tower of Basel: The Shadowy History of the Secret Bank that Runs the World. New York: Public Affairs.

Mann, M. (1997) Has globalization ended the rise and rise of the nation-state? Review of International Political Economy 4: 472-96.

Pearlstein, R. (2008) Nixonland: The Rise of a President and the Fracturing of America. New York: Scribner.

Schmitt, C. (2003 [1950]) The Nomos of the Earth in the International Law of the Jus Publicum Europaeum. New York: Telos Press.

Shaxson, N. (2011) Treasure Islands: Uncovering the Damage of Offshore Banking and Tax Havens. New York: Palgrave Macmillan.

Sokol, D. (2007) Globalization of law firms: a survey of the literature and a research agenda for future study. Indiana Journal of Global Legal Studies 14: 5-28.

Trubek, D. et al. (1994) Global restructuring and the law: studies of the internationalization of the legal fields and the creation of transnational arenas. Case Western Law Review 44: 407-98.

Wallerstein, I. et al. (2013) Uncertain Worlds: World-Systems Analysis in Changing Times. Boulder CO: Paradigm.

Wedel, J. R. (2004) Blurring the state-private divide: flex organizations and the decline of accountability, in M. Spoor (ed.) Globalization, Poverty and Conflict. Dordrecht, Netherlands: Kluwer, pp. 217-35.

Xu, Y. and Bahgat, G. (eds.) (2011) The Political Economy of Sovereign Wealth Funds. New York: Palgrave Macmillan. 